\title{
Intervention in Learning Strategies: Study with New University Students ${ }^{1}$
}

\author{
Rosana Maria Mohallem Martins², Acácia Aparecida Angeli dos Santos ${ }^{3}$ \\ ${ }^{2}$ Centro Universitário de Itajubá, Itajubá-MG, Brazil \\ ${ }^{3}$ Universidade São Francisco, Campinas-SP, Brazil
}

\begin{abstract}
Psychoeducational intervention programs in higher education can contribute to academic success. This research aimed to verify the effects of a program for the development of learning strategies in university students. The design used was quasiexperimental, with pre-test, intervention and three post-tests. 83 students participated, of which 59 were from the Control Group and 24 from the Experimental Group. It was used in the pre-test and post-tests the Learning Strategies Scale for University Students (LSSUS). The results in the post-tests revealed qualitative but not quantitative differences. The data allowed us to reflect on the impact of enrollment in higher education and to confirm the need to teach self-regulated learning strategies from the first year of graduation. The lack of previous knowledge, high expectations, as well as the number of intervention sessions were variables that possibly interfered in the results, not allowing, from a statistical point of view, a significant increase in the scale scores.
\end{abstract}

Keywords: learning, self-regulation of learning, educational psychology, higher education

\section{Intervenção em Estratégias de Aprendizagem: Estudo com Universitários Ingressantes}

\begin{abstract}
Resumo: Programas de intervenção psicoeducacional no ensino superior podem contribuir para o sucesso acadêmico. Esta pesquisa teve como objetivo verificar os efeitos de um programa para o desenvolvimento de estratégias de aprendizagem em universitários. O delineamento usado foi quase-experimental, com pré-teste, intervenção e três pós-testes. Participaram da pesquisa 83 estudantes, sendo 59 do Grupo Controle e 24 do Grupo Experimental. Foi utilizada no pré e pós-testes a Escala de Estratégias de Aprendizagem para Universitários (EEA-U). Os resultados nos pós-testes revelaram diferenças qualitativas, mas não quantitativas. Os dados permitiram refletir sobre o impacto do ingresso no ensino superior e confirmar a necessidade de se ensinar estratégias de aprendizagem autorreguladas, desde o primeiro ano da graduação. A falta de conhecimentos prévios, as altas expectativas, bem como o número de sessões de intervenção foram variáveis que possivelmente interferiram nos resultados, não permitindo, do ponto de vista estatístico, o aumento significativo nos escores da escala.
\end{abstract}

Palavras-chave: aprendizagem, autorregulação da aprendizagem, psicologia educacional, ensino superior

\section{Intervención en Estrategias de Aprendizaje: Estudio con Universitarios Ingresantes}

\begin{abstract}
Resumen: Los programas de intervención psicoeducativa en la enseñanza superior pueden contribuir al éxito académico. Esta investigación tuvo como objetivo verificar los efectos de un programa para el desarrollo de estrategias de aprendizaje en universitarios. El delineamiento utilizado fue casi-experimental, con prueba previa, intervención y tres pruebas posteriores. Participaron de la investigación 83 estudiantes, siendo 59 del Grupo Control y 24 del Grupo Experimental. Se utilizó en las pruebas previas y posteriores la Escala de Estrategias de Aprendizaje para Universitarios (EEA-U). Los resultados en las pruebas posteriores revelaron diferencias cualitativas, pero no cuantitativas. Los datos permitieron reflexionar sobre el impacto del ingreso en la enseñanza superior y confirmar la necesidad de enseñar estrategias de aprendizaje autorreguladas desde el primer año del grado. La falta de conocimientos previos, las altas expectativas, así como el número de sesiones de intervención fueron variables que posiblemente interfirieron en los resultados, no permitiendo, desde el punto de vista estadístico, el aumento significativo en los escores de la escala.
\end{abstract}

Palabras clave: aprendizaje, autorregulación del aprendizaje, psicología educativa, enseñanza superior

\footnotetext{
${ }^{1}$ Article derived from the doctoral thesis of the first author under the supervision of the second, defended in 2016, in the Post-Graduate Program in Psychology of the University of São Francisco. Support: This study was financed in part by the Coordination for the Improvement of Higher Education Personnel - CAPES - Finance Code 001

Correspondence Address: Rosana Maria Mohallem Martins. Centro Universitário de Itajubá. Av. Antônio Braga Filho, 687, Itajubá-MG, Brazil. CEP 37.505-131. E-mail: rosanamohallem@gmail.com
}

Knowing how to study is one of the determinants of academic performance and learning strategies are facilitating instruments for learning to occur. They consist of resources that the student uses at the time of study that assist in the acquisition, retention, retrieval and use of information. When the student appropriates the strategies, he or she becomes 
more competent in his or her studies, increasing the chances of academic success (Pelton, 2014; Weinstein, Acee, \& Jung, 2011). Given the importance of the topic, what is proposed in this article is the investigation of how much an intervention program in learning strategies favors its use.

It is worth mentioning that learning strategies play an important role in self-regulation (Kim, Wang, Ahn, \& Bong, 2015; Weinstein et al., 2011). It has been gaining prominence in Educational Psychology and is a self-directed, conscious and voluntary process, associated with the transformation of mental abilities into academic competences, allowing the control of one's own behaviors, thoughts and feelings (Zimmerman \& Schunk, 2011).

To synthesize the many existing definitions, Boruchovitch and Santos (2006) consider learning strategies as sequences of procedures chosen to facilitate the acquisition, storage and use of information. As highlighted by Weinstein et al. (2011) the task of defining learning strategies is challenging and, as a result, there are many existing categorizations that organize them in different ways. Despite this, there is a convergence among scholars that learning strategies do not only involve the use of cognition and metacognition, but also encompass other emotional processes such as motivation, affection, and engagement.

The importance of the appropriate use of learning strategies has been recognized in the different levels of schooling, but especially in higher education, during which there is a marked increase in the requirement of abstraction, hypothesis formation and study autonomy (Boruchovitch \& Santos, 2015; Patall, Awad, \& Cestone, 2014). Research has shown that students who do not use effective learning strategies have little concern for their own difficulties, do not adequately manage time, do not know strategies to prepare for tests and have little metacognitive knowledge (de la Fuente, Martínez-Vicente, Salmerón, Vera, \& CardelleElawar, 2016; McCabe, 2011).

In a meta-analysis study conducted by Dent and Koenka (2016), it was evidenced that variables such as level of intelligence, socioeconomic status, parents' schooling, entry grade at university, among others are predictive of a good academic performance. However, the identification of cognitive and metacognitive self-regulatory learning strategies associated with the ability to seek help to manage time can be particularly important in predicting academic success and improving student learning. Based on this study, Zollanvari, Kizilirmak, Kho and Hernández-Torrano (2017) created a mathematical model in which they inserted the intervention variable for the development of self-regulated learning strategies and concluded that with this intervention it would be possible to produce an incremental effect for a good academic performance.

Studies that focus on intervention programs for university students to improve study methods generally address the use of learning strategies and bring important elements in discussing their contributions and limitations. The literature shows that they are most often done abroad, but there are a few implemented in Brazil, as reported below, in chronological order.
Some researches carried out with Portuguese university students were carried out by Portuguese and Spanish researchers. Most of them were carried out with new students and implied the use of intervention programs to promote selfregulation and the use of learning strategies. From the various studies of this group, Rosário et al. (2005, 2007). Núñes et al. (2011) and Rosário et al. (2010), the focus variables were declarative knowledge of learning strategies, self-regulation of learning, perceived instrumentality of learning strategies, among others, and significant increases were detected in the post-test. These changes were not always detected by statistical differences, since in some cases they were the result of qualitative analyses.

Other intervention studies were carried out in the USA, and Cazan (2013) study was recovered with 79 students of the $1^{\text {st }}$ year of psychology in the discipline of Educational Psychology during a semester. The results showed that teaching to teach the combined use of metacognitive and cognitive strategies increases the ability of self-regulation. In relation to Pelton's (2014) work with 84 sociology undergraduates, specific interventions were carried out to develop learning strategies to evaluate and to what extent they developed over five semesters of the undergraduate program. The pretest and the various post-tests, in which the learning strategies were evaluated, revealed that the students began to reflect on the effectiveness of their strategies, using them more adequately only at the end of the last semester.

Among the national studies, the Freitas-Salgado (2013) study stands out, focusing on the teaching of learning strategies and study habits for $1^{\text {st }}$ year students. Participants were divided into an experimental group (26 students) and control (40 students). The results showed that the students in the experimental group were significantly higher than those in the control group. Also, Alcará and Santos (2015) conducted an intervention program with 22 students in the experimental group and 19 students in the control group. The authors focused on learning strategies and reading comprehension. In the end, the comparison of the averages showed that there was a small improvement in the learning strategies, without statistical significance, but detected through qualitative analysis. However, there was significant improvement in reading comprehension as measured by the Cloze Test.

The studies reported show the importance of promoting intervention programs that develop learning strategies. The offering of activities with this purpose, have revealed that it is possible to increase the appropriate use of these strategies, although sometimes this improvement only appears in the qualitative analyses. Based on the theoretical aspects and existing empirical data, it would be expected that participation in a psycho-pedagogical intervention program would impact the self-regulatory processes of learning, favoring the appropriate use of learning strategies. From this perspective, considering the small number of existing intervention research, the present study had the objective of evaluating an intervention program to develop the use 
and maintenance of learning strategies in students entering higher education.

\section{Method}

\section{Participants}

83 university students participated in this study, being 59 of the Control Group (CG) and 24 of the Experimental Group (EG). The EG was comprised of 08 (33.3\%) male students and 16 (66.7\%) female students; 22 (91.7\%) were younger or up to 21 years of age; $1(4.2 \%)$ from 22 to 24 years and $1(4.2 \%)$ over 25 years. About the courses, $10(41.7 \%)$ students attended Psychology; 3 (12.5\%) Production Engineering; 3 (12.5\%) Physical Education and $8(33.3 \%)$ Veterinary Medicine. From the CG, 40 $(67.8 \%)$ male students and $19(32.2 \%)$ female students participated; $41(69.5 \%)$ were younger or up to 21 years of age; $10(16.9 \%)$ between 22 to 24 and $8(13.6 \%)$ over 25 years. 5 studied Psychology (8.5\%); 19 (32.2\%) Production Engineering; 16 (27.1\%) Physical Education and $19(32.2 \%)$ Veterinary Medicine. Participation in the research was offered to all course coordinators, but it was the coordinators of these courses who agreed to make the proposal known to the students.

\section{Instruments}

In the intervention sessions, materials such as slides with the thematic contents worked in each session were used. In addition, texts, colored pens and blank sheets of paper were also used. In the pre- and post-tests, the Learning Strategies Scale for University Students (LSS-US) of Boruchovitch and Santos (2015) described below was used.

Escala de Estratégias de Aprendizagem para Universitários - EEA-U (Boruchovitch \& Santos, 2015). Likert scale of three points, consisting of 35 items referring to the way students usually study. It was applied in 1490 university students, presenting high internal consistency with Cronbach's alpha $(\alpha=0.87)$. Factor analysis revealed the existence of three factors. The Factor 1 Cognitive and Metacognitive Self-Regulation $(\alpha=0.86)$ evaluates a set of cognitive and metacognitive strategies. Examples of items in this factor are "repeat the information orally as you read the text" and "summarize the texts indicated for the study." Factor 2, Self-Regulation of Internal and Contextual Resources $(\alpha=0.71)$, refers to the set of strategies oriented to the control and management of internal states and contextual variables that interfere in the self-regulation of learning. Statements such as "controlling your anxiety in assessment situations" and "managing your study time" are examples of items in this factor. Finally, Factor 3, Social Self-Regulation $(\alpha=0.65)$ is related to the strategies directed to the ways of learning that involve interaction with the other. Examples of items that evaluate this factor are "ask for help to colleagues in case of doubts" and "study in group".

\section{Procedures}

Data collection. The research began with the authorization of the coordinators and the consent of the students. The pre-test was carried out at the end of the second month of the beginning of the classes and consisted of the application of the Learning Strategies Scale. After application, the students were invited to participate in the Learning Strategies Workshops, being offered after the last lesson on the day of the week that they had only four classes.

The workshops were organized into four groups divided by area of knowledge. There were six sessions lasting one hour. All the sessions had the same structure, starting with a rapport to leave the students at ease and facilitate the participation, then a review of the strategies taught in the previous session and, finally, the management and discussion of the training activities of the learning strategies prepared for the day. The intervention program aimed to develop cognitive and metacognitive self-regulation strategies, selfregulation of internal and contextual resources, and social self-regulation, as can be seen in Table 1 .

Table 1

Learning Strategies and Purposes of Each Session

\begin{tabular}{|c|c|}
\hline Session & Types of strategies and aspects focused \\
\hline $1^{\mathrm{a}}$ & $\begin{array}{l}\text { Strategies of metacognitive self-regulation of } \\
\text { planning and strategies for self-regulation of } \\
\text { the contextual resources } \\
\text { Setting objectives, managing time, structuring } \\
\text { the environment }\end{array}$ \\
\hline $2^{\mathrm{a}}$ & $\begin{array}{l}\text { Strategies of cognitive self-regulation of essay, } \\
\text { organizational elaboration and metacognitive } \\
\text { monitoring. } \\
\text { Short-term memory and long-term memory }\end{array}$ \\
\hline $3^{\mathrm{a}}$ & $\begin{array}{l}\text { Strategies of cognitive self-regulation of } \\
\text { elaboration } \\
\text { Organization of information: annotations, } \\
\text { abstracts }\end{array}$ \\
\hline $4^{\mathrm{a}}$ & $\begin{array}{l}\text { Strategies of cognitive self-regulation of } \\
\text { elaboration } \\
\text { Organization of information: Cornell } \\
\text { technique }\end{array}$ \\
\hline $5^{\mathrm{a}}$ & $\begin{array}{l}\text { Strategies of Cognitive Self-Regulation } \\
\text { Organization of information: conceptual maps }\end{array}$ \\
\hline $6^{\mathrm{a}}$ & $\begin{array}{l}\text { Self-regulation strategies for internal } \\
\text { resources } \\
\text { Anxiety in the face of evidence. Preparation } \\
\text { for exams }\end{array}$ \\
\hline
\end{tabular}

After the interventions, three post-tests were performed. The first one was carried out four months after the interventions, the second six months and the last, one year after the interventions. Post-test I and Post-test III consisted of the application of the Learning Strategies Scale for University Students (LSS-US) by Boruchovitch 
and Santos (2015). Post-test II was performed by completing a questionnaire, with the following questions: (1) How did you attend the workshops?; (2) Tell about whether your way of studying has changed after the workshop; (3) Which strategy(ies) do you use most often?; (4) Write a little about how you studied before and how you studied later; (5) How do you evaluate your academic performance before and after the workshops? Have the grades improved?

Depending on the availability of participants, the sample number differed in post-test II and III. Post-test II had the participation of 12 university students, six of them being from the Psychology Course and six from the Physical Education Course. Post-test III totaled thirty-two participants, fourteen of EG and eighteen of CG. The experimental group had nine participants from the Psychology Course, two from the Physical Education Course and three from the Production Engineering Course.

Data analysis. To meet the objectives, the nonparametric analyses were used because of the number of participants of the EG and CG. The Mann-Whitney test was used to compare two independent groups and the Wilcoxon test was used for intragroup comparisons. Spearman's correlation was used to verify the association between the two measurements in both EG and CG. For the analysis of the responses in Post-test II an analysis of the prevalence of the answers for each of the questions was made.

\section{Ethical Considerations}

The Project of this research was sent to the ethics committee of the São Francisco University (CAAE: 21449213.1.0000.5514), being approved according to the opinion 472.782 .

\section{Results}

\section{Comparison of Measures of EG and CG in the Pretest}

The performance of the students in the pre-test of the EG and of the CG in the Learning Strategies Scale, using the Mann-Whitney U test, was verified through descriptive statistics. The results can be seen in Table 2 .

Table 2

Comparison of the Performance of the Participants of the EG and CG in the Pre-Test in the Measurement of Learning Strategies
Measures
$\mathrm{EG}(n=24)$
$\mathrm{CG}(n=59)$

\begin{tabular}{|c|c|c|c|c|c|c|c|c|c|c|c|c|}
\hline & Min & Max & $M$ & $S D$ & M Rank & Min & Max & $M$ & $S D$ & $\begin{array}{c}M \\
\text { Rank }\end{array}$ & $U$ & $p$ \\
\hline $\begin{array}{l}\text { Cognitive } \\
\text { Metacognitive } \\
\text { Self-regulation }\end{array}$ & 35 & 64 & 47.96 & 7.83 & 43.15 & 27 & 68 & 47.22 & 9.21 & 41.53 & 680.50 & 0.78 \\
\hline $\begin{array}{l}\text { Self-Regulation } \\
\text { Internal and } \\
\text { Contextual } \\
\text { Resources }\end{array}$ & 7 & 22 & 16.17 & 3.99 & 41.27 & 9 & 22 & 16.47 & 3.56 & 42.30 & 690.50 & 0.86 \\
\hline $\begin{array}{l}\text { Social } \\
\text { Self-Regulation }\end{array}$ & 4 & 11 & 8.63 & 1.83 & 48.65 & 3 & 12 & 7.93 & 1.91 & 39.30 & 548.50 & 0.10 \\
\hline $\begin{array}{l}\text { Learning } \\
\text { Strategies } \\
\text { Total }\end{array}$ & 51 & 96 & 72.75 & 11.95 & 44.10 & 43 & 102 & 71.62 & 12.51 & 41.14 & 657.50 & 0.61 \\
\hline
\end{tabular}

The data in Table 2 show the results obtained in the scale dimensions of learning strategies in the EG and CG in the pre-test. It was observed that there was no statistically significant difference between the groups, since they can be attributed to chance.

\section{Comparison of Measures Pre and Post-test I for EG and CG}

Intragroup differences were investigated by means of the comparison of the means in the pre and post-tests for the EG. The test used for the analysis was the Wilcoxon Signed Ranks, which shows the number of participants who improved their performance, those who remained in the same position and those who worsened the performance in the post-test. The data can be seen in Table 3 . 
Table 3

Intragroup Comparison of the Performance of the Students of the EG in the Pre-test and Post-test I

\begin{tabular}{|c|c|c|c|c|c|c|}
\hline \multirow{2}{*}{ Measures } & \multicolumn{6}{|c|}{$\mathrm{EG}(n=24)$} \\
\hline & $M$ & Ranks & $N$ & M by Ranks & Z & $p$ \\
\hline Self-Regulation of Internal and Contextual Resources (post-test) & 46.63 & Negatives & 12 & 10.38 & & \\
\hline \multirow[t]{2}{*}{ Self-Regulation of Internal and Contextual Resources (pre-test) } & 47.96 & Positives & 7 & 9.36 & -1.18 & 0.23 \\
\hline & & Draws & 5 & & & \\
\hline Self-Regulation of Internal and Contextual Resources (post-test) & 16.50 & Negatives & 7 & 9.71 & & \\
\hline \multirow[t]{2}{*}{ Self-Regulation of Internal and Contextual Resources (pre-test) } & 16.17 & Positives & 11 & 9.36 & -0.76 & 0.44 \\
\hline & & Draws & 6 & & & \\
\hline Social Self-regulation (post-test) & 8.25 & Negatives & 12 & 10.04 & & \\
\hline \multirow[t]{2}{*}{ Social Self-regulation (pre-test) } & 8.62 & Positives & 7 & 9.93 & -1.04 & 0.29 \\
\hline & & Draws & 5 & & & \\
\hline $\begin{array}{l}\text { Total Learning Strategies } \\
\text { (post-test) }\end{array}$ & 71.38 & Negatives & 14 & 13.61 & & \\
\hline \multirow[t]{2}{*}{ Total Learning Strategies (pre-test) } & 72.75 & Positives & 10 & 10.95 & -1.16 & 0.24 \\
\hline & & Draws & 0 & & & \\
\hline
\end{tabular}

As can be seen in Table 3, there was no significant difference in the results of the pre- and post-test I for the EG. Thus, the hypothesis that the scores on the learning strategy scale would be higher in the post-test compared to those obtained in the pre-test for the EG was not confirmed.
Table 4 shows the results of the pre-test and of the posttest I for the CG. The same statistical test was used, Wilcoxon Signed Ranks.

Table 4

Intragroup Comparison of the Performance of the Students of the CG in the Pre-test and Post-test I

\begin{tabular}{|c|c|c|c|c|c|c|}
\hline \multirow[b]{2}{*}{ Measures } & \multicolumn{6}{|c|}{ Control Group $(n=59)$} \\
\hline & $M$ & Ranks & $N$ & $\begin{array}{l}\text { M by } \\
\text { Ranks }\end{array}$ & $\mathrm{Z}$ & $p$ \\
\hline Cognitive and Metacognitive Self-Regulation (post-test) & 47.22 & Negatives & 27 & 32.48 & & \\
\hline \multirow[t]{2}{*}{ Cognitive and Metacognitive Self-Regulation (pre-test) } & 47.22 & Positives & 31 & 26.90 & -0.16 & 0.86 \\
\hline & & Draws & 1 & & & \\
\hline Self-Regulation of Internal and Contextual Resources (post-test) & 16.63 & Negatives & 26 & 24.15 & & \\
\hline \multirow[t]{2}{*}{ Self-Regulation of Internal and Contextual Resources (pre-test) } & 16.47 & Positives & 25 & 27.92 & -0.32 & 0.74 \\
\hline & & Draws & 8 & & & \\
\hline Social Self-regulation (post-test) & 7.61 & Negatives & 26 & 27.67 & & \\
\hline \multirow[t]{2}{*}{ Social Self-regulation (pre-test) } & 7.93 & Positives & 24 & 23.15 & -0.80 & 0.42 \\
\hline & & Draws & 9 & & & \\
\hline Total Learning Strategies (post-test) & 71.62 & Negatives & 30 & 28.62 & & \\
\hline \multirow[t]{2}{*}{$\begin{array}{l}\text { Total Learning Strategies } \\
\text { (pre-test) }\end{array}$} & 71.46 & Positives & 27 & 29.43 & -0.25 & 0.79 \\
\hline & & Draws & 2 & & & \\
\hline
\end{tabular}


As can be seen in Table 4, there was no significant difference in the pre and post-test I results for the CG regarding learning strategies. Thus, the hypothesis that there would be no statistically significant difference in the CG students' scores for not attending the workshops was confirmed.

\section{Post-Test II}

Post-test II occurred one month after the end of posttest I. The set of responses to each question was the object of material exploration and the prevalence of each was analyzed, without accounting for the frequency percentage. Regarding the first question of the questionnaire (how did they attend in the workshops?), The predominance was the affirmation that they benefited from the activities developed in the sessions, reporting that they had improved their study strategies. They mentioned the learning of new techniques for the elaboration of abstracts, as well as the formulation of questions, perfecting the cognitive strategies of elaboration. The self-regulation strategies of internal and contextual resources were also mentioned, as well as the reduction of anxiety before the tests and the organization for the studies.

For the second question, regarding strategies, the abstract was indicated as the most commonly used strategy, being highlighted by the students that it happened to be done in a more critical way. Self-regulation strategies of internal and contextual resources were also cited, such as the preparation of the study environment, as well as the ability to concentrate and decrease anxiety. Studying in a group was another strategy that was mentioned by some students.
Faced with the third question of the questionnaire, comparing how the student studied before and after the workshops, the students again reported the elaboration of the abstract, but now associated with a more critical and thorough reading. The strategy of self-regulation of contextual resources is also mentioned, as well as the improvement in the administration of time for the study. The strategy of social self-regulation was once again pointed out by the students as a strategy that began to be used to seek help for the interpretation of content. On the fourth and last question in the questionnaire, the students answered about their performance. When comparing what it was like before and after the workshops, they reported that the notes had improved.

\section{Post-Test III}

Post-test III occurred one year after the workshops, and the Learning Strategies Scale was again applied to the participants, when students were already in the 3rd period of Psychology, Physical Education and Production Engineering courses. As in post-test I, non-parametric analyses were used because of the number of the EG and CG samples. The Wilcoxon Signed Ranks test was used for intragroup comparisons, that is, the results of the same students were compared in the pre and post-test I for the EG. The hypothesis is that there would be a significant difference between the results of the same students, higher for the EG, one year after the beginning of the course, considering that the experience in higher education can interfere in the use of learning strategies. The data obtained can be seen in Table 5.

Table 5 .

Intragroup Comparison of the Performance of the Students of the EG in the Pre-test and Post-test III

\begin{tabular}{|c|c|c|c|c|c|c|}
\hline \multirow[b]{2}{*}{ Measures } & \multirow[b]{2}{*}{$M$} & \multicolumn{5}{|c|}{$\mathrm{EG}(n=14)$} \\
\hline & & Ranks & $N$ & $\begin{array}{l}\text { Mby } \\
\text { Ranks }\end{array}$ & $\mathrm{Z}$ & $p$ \\
\hline Cognitive and Metacognitive Self-Regulation (post-test III) & 46.61 & Negatives & 9 & 6.89 & & \\
\hline \multirow[t]{2}{*}{ Cognitive and Metacognitive Self-Regulation (pre-test) } & 47.64 & Positives & 5 & 8.60 & -0.59 & 0.55 \\
\hline & & Draws & 0 & & & \\
\hline $\begin{array}{l}\text { Self-Regulation of Internal and Contextual Resources } \\
\text { (post-test III) }\end{array}$ & 17.00 & Negatives & 8 & 5.88 & & \\
\hline \multirow{2}{*}{$\begin{array}{l}\text { Self-Regulation of Internal and Contextual Resources (pre- } \\
\text { test) }\end{array}$} & 16.64 & Positives & 6 & 9.67 & -0.34 & 0.72 \\
\hline & & Draws & 0 & & & \\
\hline Social Self-regulation (post-test III) & 7.57 & Negatives & 11 & 6.86 & & \\
\hline \multirow[t]{2}{*}{ Social Self-regulation (pre-test) } & 8.64 & Positives & 2 & 7.75 & -2.12 & 0.03 \\
\hline & & Draws & 1 & & & \\
\hline Total Learning Strategies (post-test III) & 71.29 & Negatives & 8 & 6.81 & & \\
\hline \multirow[t]{2}{*}{$\begin{array}{l}\text { Total Learning Strategies } \\
\text { (pre-test) }\end{array}$} & 72.93 & Positives & 5 & 7.30 & -0.62 & 0.52 \\
\hline & & Draws & 1 & & & \\
\hline
\end{tabular}


From Table 5, it can be observed that there was no significant difference in the pre and post-test III results for the EG regarding learning strategies, considering the total result. When the factors were analyzed separately, a significant difference was detected in the scores of social self-regulation strategies, revealing that students, after one year of higher education, decreased the use of strategies that involved interaction with each other, such as the group study and clarification of doubts with colleagues.

As it was not expected that the use of strategies of social selfregulation would decrease over the years in higher education, the scores obtained by the students of each of the courses were examined. The purpose was to identify if the phenomenon was located in any of them in particular. Based on the inspection done, it was verified that the decrease occurred with the students of two of the courses (Physical Education and Psychology).

\section{Discussion}

With the aim of evaluating an intervention program to develop learning strategies in new university students, the promotion of self-regulated learning was also sought. The post-test measures were expected to increase scale scores, revealing changes in the frequency of use of learning strategies. Regarding the measures of the pre-test and posttest I and III, no changes were identified in the expected direction. For having been associated with the quantitative analyses carried out in Post-tests I and III, the qualitative analysis of the responses in Post-test II, it was possible to identify elements that would not have been obtained otherwise, speaking in favor of the use of resources that are not exclusively quantitative. When reflecting on possible variables that would have interfered in the results of the pretest and posttest I, some explanatory hypotheses have been raised and will be presented and discussed in the sequence.

A first question concerns the time elapsed between the pre-test and the post-test I. As the closure of the intervention sessions took place approximately fifteen days before the vacations, and in just one month after the return to school, post-test 1 was applied, it is possible to conjecture that there was little time for the students to put into practice the contents worked in the intervention sessions.

The duration of the intervention process has been considered as a potential variable of interference in the results. Studies such as that of Rosário et al. (2005) and Alcará and Santos (2015), had a total of sessions 6 and 12 hours respectively and in both, no significant differences were found in the means of learning strategies from pre to post-test. On the other hand, in the study carried out by Cazan (2013), where interventions lasted one semester, a significant difference was found only in the third post-test performed at the end of the last semester.

Differences have been reported, however, only for some focused variables. In the study by Rosário et al. (2007), whose duration was also six hours, there was a significant difference for the variable knowledge of learning strategies, but not in terms of the deep approach and perceived instrumentality for self-regulation. In a later study, Rosário et al. (2010) applied a nine-hour intervention program and did not find a significant difference in the perceived instrumentality variable of learning strategies, considered by them as the most important, since it leads them to perceive its applicability in day-to-day life. In the same direction, in the program of Freitas-Salgado (2013), lasting nine hours, there was a significant difference for selfregulation of learning and instrumentality for self-regulation. However, it is also necessary to consider other aspects that may have been critical for explaining the absence of positive changes that were statistically detected. Among these aspects, some assumptions can be made regarding the narrow focus of the program exclusively on strategies of self-regulation of learning. It is quite likely that the joint work of these strategies with other psychological processes such as motivation and self-efficacy, particularly, would work for more expressive changes to be achieved.

In the present study, despite the little expressive results of post-test I, it was possible to observe that post-test II revealed important data such as improvement in study habits through increased use of strategies that were already used and learning of new strategies, leading to an increase in grades. The most mentioned strategies in the answers were the cognitive strategies of elaboration, like the abstracts, annotations in the classroom; self-regulation of internal and contextual resources, such as anxiety reduction and better time management for the study, as well as the strategy of social self-regulation, such as group study.

However, despite the improvement admitted by the respondents, it was possible to observe that the metacognitive strategies were little mentioned by them. This data corroborates the study by Stegers-Jager, Cohen-Schotanus and Themmen (2012) that revealed that performance in the first year of graduation appears little associated with the use of metacognitive strategies. Similarly, in Marini and Boruchovitch's (2014) research it was found that simpler strategies (repeat, rewrite) are more common in the early years and decrease over the university experience. However, metacognitive strategies, which involve the evaluation of the use of cognitive strategies, tend to increase their frequency during the formative years. The same happened in studies like those of Núñez et al. (2011) and Rosário et al. (2007, 2010), in which the impact of the intervention was greater on simpler cognitive strategies, since its applicability did not occur immediately.

Post-test III occurred one year after the interventions in the workshops, and the Learning Strategies Scale was again applied to the participants, however, already attending the 3rd period of the Psychology, Physical Education and Production Engineering courses. The hypothesis is that there would be a significant difference between the results of the same students, higher for the EG, one year after the beginning of the university, considering that the experience in higher education can interfere in the habits of study and the use of learning strategies. There was no significant difference in the pre and post-test III results for the EG in most of the factors, except for the social self-regulation strategy, in which surprisingly there was a significant decrease in the scores. Alternative hypotheses can be 
raised. One of them would be related to the existence of other concomitant psychological processes that were not focused on the intervention program, such as self-efficacy, motivation and engagement, for example. They may have been determinants of changes that could not be captured by the learning strategies tool used in the present study. Another critical point is related to the instrument chosen for the evaluation of strategies, since Factor 3 (social self-regulation) was the one that presented the lowest estimate of accuracy. Such fragility could be responsible for not providing the most adequate interpretation of the phenomenon evaluated. In addition, it is important to point out that of the 24 EG students, only 14 students participated in Posttest III, which can also affect the reliability of the results due to the marked experimental decrease (58.33\%). A last aspect can be commented here, which concerns the Psychology class, who experienced a specific relationship difficulty in the 2nd year of the course, which was verified by informal reports from the participants themselves and from the course teachers. This fact could be raised as a rival hypothesis, potentially explaining the decrease in the scores of the nine students of this course, who participated in this last phase of the post-test.

In summary, the results in the post-tests, both carried out four months after the interventions, such as after a year revealed no differences were considered significant and were closely related to the intervention process. The use of simple cognitive strategies was more prevalent in this study, being verified both in the quantitative and qualitative analyses, through the questionnaire, corroborating with other studies that also evaluated new students. This data confirms the need and urgency to work on the self-regulation strategies of learning in the university, developing the active, reflexive and critical posture of university students. Particularly, the focus of these educational actions needs to be focused on the development of metacognitive strategies that are broader and involve the regulation and evaluation of the use of cognitive strategies, whose importance is recognized in the meta-analysis study of Dent and Koenka (2016) as predictive of academic performance.

In terms of final considerations, it is considered that this research contributed to broaden the knowledge about the use of learning strategies of new university students, as well as the specifics of the application of an intervention program in the first semester of graduation. Studies like this are relevant because they contribute to the improvement of training in higher education. The limitations detected are related to the time spent on the interventions, which appeared to be insufficient for the student to become familiar with the application of the strategies in various situations and activities. The period of application of the intervention program in the first semester may have been another limitation, given the need of the new student to have a period of living to adapt to the new context, with new challenges and new requirements. In addition, the exclusive focus on self-regulating learning strategies does not seem to be enough to support intervention programs, for which it may be necessary that constructs highly related to the use of strategies have to be simultaneously worked on. This limitation may serve as an aid to the proposal of future programs to consider it. Finally, it is worth mentioning as a limitation the long time passed until the application of the last post-test. In addition to the marked experimental decrease, the long intercurrent time between Post-test II and Post-test III does not allow that any changes or non-changes can be attributed solely to the effect of the intervention program, as it seems to have occurred with the students of Psychology.

New studies are necessary and urgent to fill gaps in research on this stage of schooling. Suggestions for these studies, especially for interventional studies, as well as the question of involving other related psychological processes, should attend to the need for more time allocated to the sessions. It would be important, however, for intervention programs with this purpose to be included in the Political Pedagogical Projects of undergraduate programs, and there may be a specific discipline for this purpose, regardless of the training area. In it, there would be the proposal to accompany and welcome the student into the process of academic insertion, enabling the whole cycle of self-regulation to be installed to favor the development of learning strategies.

\section{References}

Alcará, A. R., \& Santos, A. A. A. (2015). Avaliação e desenvolvimento da compreensão de leitura em universitários. Estudos de Psicologia (Campinas), 32(1), 63-73. doi:10.1590/0103-166X2015000100006

Boruchovitch, E., \& Santos, A. A. A. (2006). Estratégias de aprendizagem: Conceituação e avaliação. In A. P. P. Noronha, A. A. A. Santos, \& F. F. Sisto (Orgs.), Facetas do fazer em avaliação psicológica (pp. 107-124). São Paulo, SP: Vetor.

Boruchovitch, E., \& Santos, A. A. A. (2015). Psychometric studies of the learning strategies scale for university students. Paidéia (Ribeirão Preto), 25(60), 19-27. doi:10.1590/1982-43272560201504

Cazan, A.-M. (2013). Teaching self regulated learning strategies for psychology students. Procedia - Social and Behavioral Sciences, 78, 743-747. doi:10.1016/j. sbspro.2013.04.387

de La Fuente, J., Martínez-Vicente, J. M., Salmerón, J. L., Vera, M. M., \& Cardelle-Elawar, M. (2016). Actionemotion style, learning approach and coping strategies in undergraduate university students. Anales de Psicología, 32(2), 457-465. doi:10.6018/analesps.32.2.197991

Dent, A. L., \& Koenka, A. C. (2016). The relation between selfregulated learning and academic achievement across childhood and adolescence: A meta-analysis. Educational Psychology Review, 28(3), 425-474. doi:10.1007/s10648-015-9320-8

Freitas-Salgado, F. A. (2013). Autorregulação da aprendizagem: Intervenção com alunos ingressantes do ensino superior [Self-regulation learning: Intervention with higher education freshman] (Doctoral dissertation). Retrieved from http:// repositorio.unicamp.br/bitstream/REPOSIP/250814/1/ Freitas-Salgado_FernandaAndradede_D.pdf 
Kim, D.-H., Wang, C., Ahn, H. S., \& Bong, M. (2015). English language learners' self-efficacy profiles and relationship with self-regulated learning strategies. Learning and Individual Differences, 38, 136-142. doi:10.1016/j.lindif.2015.01.016

Marini, J. A. S., \& Boruchovitch, E. (2014). Estratégias de aprendizagem de alunos brasileiros do ensino superior: Considerações sobre adaptação, sucesso acadêmico e aprendizagem autorregulada [Learning strategies of Brazilian students in higher education: Considerations about the adaptation, academic success and self-regulated learning]. Revista E-Psi: Revista Eletrônica de Psicologia, Educação e Saúde, 4(1), 102-126. Retrieved from http://revistaepsi.com/ wp-content/uploads/artigos/2014/Ano4-Volume1-Artigo5.pdf

McCabe, J. (2011). Metacognitive awareness of learning strategies in undergraduates. Memory \& Cognition, 39(3), 462-476. doi:10.3758/s13421-010-0035-2

Núñez, J. C., Cerezo, R., Bernardo, A., Rosário, P., Valle, A., Fernández, E., \& Suárez, N. (2011). Implementation of training programs in self-regulated learning strategies in Moodle format: Results of an experience in higher education. Psicothema, 23(2), 274-281. Retrieved from http://www.psicothema.com/PDF/3882.pdf

Patall, E. A., Awad, G. H., \& Cestone, C. M. (2014). Academic potential beliefs and feelings: Conceptual development and relations with academic outcomes. Self and Identity, 13(1), 58-80. doi:10.1080/15298868.2012.738705

Pelton, J. A. (2014). How our majors believe they learn: Student learning strategies in an undergraduate theory course. Teaching Sociology, 42(4) 277-286. doi:10.1177/0092055X14542351

Rosário, P., Mourão, R., Núñez, J. C., González-Pienda, J., Solano, P., \& Valle, A. (2007). Eficacia de un programa instruccional para la mejora de procesos y estrategias de aprendizaje en la enseñanza superior [Evaluating the efficacy of a program to enhance college students' self-regulation learning processes and learning strategies]. Psicothema, 19(3), 422-427. Retrieved from http://www.psicothema.com/pdf/3380.pdf

Rosário, P., Mourão, R., Soares, S., Araújo, J. F., Núñez Perez, J. C., González-Pienda, J. A., ... Guimarães, C. (2005). Promover as competências de estudo na universidade: Projecto "Cartas do Gervásio ao seu umbigo" [Enhancing study competencies in higher education: Project "Letters from Gervásio to his belly-bottom]. Psicologia e Educação, 4(2), 57-69. Retrieved from http://repositorium.sdum.uminho.pt/handle/1822/11943

Rosário, P., Nunes, T., Magalhães, C., Rodrigues, A., Pinto, R., \& Ferreira, P. (2010). Processos de auto-regulação da aprendizagem em alunos com insucesso no $1^{\circ}$. ano de universidade [Self-regulated learning processes of students experiencing failure in the first year of university]. Psicologia Escolar e Educacional, 14(2), 349-358. doi:10.1590/S1413-85572010000200017
Stegers-Jager, K. M., Cohen-Schotanus, J., \& Themmen, A. P. (2012). Motivation, learning strategies, participation and medical school performance. Medical Education, 46(7), 678-688. doi:10.1111/j.1365-2923.2012.04284.x

Weinstein, C. E., Acee, T. W., \& Jung, J. (2011). Selfregulation and learning strategies. New Directions for Teaching and Learning, 2011(126), 45-53. doi:10.1002/ tl.443

Zimmerman, B. J., \& Schunk, D. H. (2011). Handbook of self-regulation of learning and performance. New York, NY: Routledge.

Zollanvari, A., Kizilirmak, R. C., Kho, Y. H., \& HernándezTorrano, D. (2017). Predicting students' GPA and developing intervention strategies based on selfregulatory learning behaviors. IEEE Access, 5, 23792 23802. doi:10.1109/ACCESS.2017.2740980

Rosana Maria Mohallem Martins is a Professor of the Fundação de Ensino e Pesquisa de Itajubá at the Centro Universitário de Itajubá, Itajubá-MG, Brazil.

Acácia Aparecida Angeli dos Santos is a Full Professor of the Universidade São Francisco, Campinas-SP, Brazil.

\section{Authors' Contribution:}

All authors made substantial contributions to the conception and design of this study, to data analysis and interpretation, and to the manuscript revision and approval of the final version. All the authors assume public responsability for content of the manuscript.

Received: Dec. 26, 2016

1st Revision: Mar. 04, 2018

Approved: Jun. 13, 2018

How to cite this article:

Mohallem, R. M. M., \& Santos, A.A.A. (2018). Intervention in learning strategies: Study with new university students. Paidéia (Ribeirão Preto), 28, e2839. doi: http://dx.doi.org/10.1590/1982-4327e2839 